Корчинский $A$. В. Оптические законы литературы : текст и действительность в советской «социологической поэтике» 1920-х гг. // Философия. ЖКунал Высшей школы экономики. - 2021. - Т. 5, № 2. - С. 123-142.

\title{
АНАТОЛИЙ КОРЧИНСКИЙ*
}

\section{ОПТИЧЕСКИЕ ЗАКОНЫ ЛИТЕРАТУРЫ**}

\author{
ТЕКСТ И АЕЙСТВИТЕЛЬНОСТЬ В СОВЕТСКОЙ \\ «СОЦИОЛОГИЧЕСКОЙ ПОЭТИКЕ》 1920-Х ГГ.
}

Получено: 15.11.2020. Рецензировано: 25.02.2021. Принято: 03.03.2021.

Аннотация: В статье рассматривается несколько научных метафор, описывающих закономерности взаимоотношений литературы и действительности в советском «социологическом» литературоведении 1920-х гг. Наиболее продуктивные из таких концептуальных метафор-отражение и преломление-раскрывают особенности ключевых марксистских или близких марксизму теорий-Плеханова, ленина, Фриче, Переверзева, Медведева, Бахтина, Волошинова и др. Отмечается характерная для эпохи тенденция к разработке универсальных научных законов применительно к явлениям культуры, предполагающая, в частности, нивелирование роли автора в историко-литературном процессе и связанного с ней критического потенциала искусства. Анализируются различные стратегии интерпретации базовых теоретических метафор, истолковываемых прежде всего как отражение/преломление социальной реальности в литературе. Обсуждается два аспекта проблемы отражения/преломления: онтологический, подразумевающий «правдивое изображение» действительности, и эпистемологический, который предполагает, что литература воспроизводит не саму действительность, а социальную оптику ее понимания. Автор статьи показывает, что оптические метафоры позволяют разобраться с тем, какие из теорий подразумевают бо́льшую зависимость литературы от господствующих социальных представлений, какие-бо́льшую независимость, гибкость и вариативность закона отражения/преломления. В этом свете рассмотрены полюса «социологической поэтики»: теории Фриче и Переверзева как последовательные версии идеологического детерминизма, подход Ленина как своеобразная деконструкция литературной идеологии и метод «бахтинского круга» как наиболее мягкая версия «социологизма», в снятом виде сочетающая его с некоторыми положениями формальной школы.

Ключевые слова: «социологическая поэтика», «социологический метод», «теория отражения», «закон идеологического преломления», классовая психология, идеология, марксизм, формализм.

DOI: $10.17323 / 2587-8719-2021-2-123-142$.

Становление теоретического литературоведения в России и СССР в 1910-20-е гг. сопровождалось усиленным поиском универсальных

*Корчинский Анатолий Викторович, к. филол. н., доцент, Институт филологии и истории Российского государственного гуманитарного университета (Москва), korchinsky® mail.ru, ORCID: 0000-0002-5087-2531.

** (C) Корчинский, А. В. () Философия. Журнал Высшей школы экономики. 
закономерностей, определяющих историческое бытие литературы. Формалисты искали их в области литературного языка и устройства текста. «Социологи», то есть те, кто полагал, что факторы, определяющие литературное развитие, а также структуру и смысл художественного текста, находятся за пределами литературы - в сфере общественной жизни. И хотя эти законы предполагали уникальность их конкретных воплощений в творчестве отдельных писателей, в целом истолкование законов литературы тяготело к признанию за ними общеобязательной силы и относительной независимости от воли отдельного автора как участника литературного процесса. При этом если формалисты изначально ставили себе задачей изучение закономерности незакономерного, стремясь вычислить векторы литературного развития, к которым ведут индивидуальные авторские решения («приемы»), являющиеся по сути аномалиями, то приверженцы «социологического метода» в различных его вариантах стали приходить к постановке вопроса об относительной «сознательности» творческого акта лишь на этапе усложнения первоначальных марксистских концепций - переосмысления искусствоведческих работ Плеханова в конце 1920-х гг., ярко проявившегося в контексте дискуссии с формалистами (Материалы диспута..., 2001: 247-278) и в ходе критики «вульгарного социологизма», а затем - в рамках догматизирующей герменевтики ленинских статей о Л. Н. Толстом.

Далее я попробую уточнить некоторые моменты развертывания этой теоретической траектории в развитии «социологического» ${ }^{1}$ литературоведения 1920-х гг., уделив внимание одному, на мой взгляд, до сих пор недостаточно осмысленному сюжету - способам концептуализации отношений между литературой и общественной реальностью в научном языке эпохи, оперировавшем такими оптическими метафорами, как «отражение» и «преломление», и придававшем обозначаемым этими словами процессам статус научного закона. Обычно при анализе «социологических» подходов к литературе, часть которых в 1930-е гг. была включена в арсенал официального советского литературоведения, а часть - отброшена, основной акцент делается на том, что общим знаменателем этих подходов является последовательный эстетический

\footnotetext{
${ }^{1}$ Я оставляю это определение в кавычках как историческое и полагаю, что далеко не во всех случаях теоретические походы этого типа могут считаться собственно социологическими, то есть действительно сопряженными с социологической наукой. В большинстве контекстов литературоведческая «социология» подразумевает лишь весьма условное указание на гипотетическую связь произведения с некоторыми внешними литературе социальными явлениями и процессами.
} 
и научный реализм. Под этим понимается не только разрабатывавшаяся в это время теория реализма как литературного стиля, но и вера в то, что литературное произведение представляет собой отображение социально-исторической действительности (Rubin, 1956: 527-542; Aucouturier, 1976: 411-426; Ermolaev, 1977: 93-98; Сухих, 2006). В свете этой установки настойчиво натурализуется не только «идейное содержание» литературы, но и элементы художественной формы, в частности сюжет произведения (Зенкин, 2012: 377-390), образы героев (там же: 391-408), жанровые структуры (Сухих, 2006). С. Н. Зенкин показывает, что, наследуя не только традициям русской критики и эстетике хІх века, но и дореволюционной теории (в частности, А. Н. Веселовскому), и советское литературоведение, и отечественная литературоведческая мысль хх века в целом (за исключением формалистов, В.Я. Проппа и структуралистов Тартуской школы) оказывается фатально и часто некритически связана с этим научным реализмом.

Однако если под таким реализмом понимать только референцию текста к внеположной реальности, то картина развития довольно обширного сегмента русской и советской теории (а не только «социологизма» 1910-20-х гг.) получается несколько однообразной. Существует еще один немаловажный аспект этой проблематики, который выделяет именно марксистские и близкие им «социологические» поэтики. Дело в том, что во всех теориях отражения / преломления речь идет не только о воспроизведении в тексте некоторой социальной реальности, но и о том, что сам текст и воплощенная в нем субъектность персонажей и автора является своеобразным оптическим устройством, специфически видоизменяющим отражаемую / преломляемую действительность. В этом смысле литература воспроизводит не саму социально-историческую действительность, а определенный тип социального воображаемого, представляющего собой специфическую версию этой действительности, обусловленную психологией и идеологией соответствующего класса. Если немного усилить этот тезис, то можно утверждать, что именно разработка законов социальной (и «социологической») оптики литературы, а не одержимость миметической репрезентацией реальности в произведении составляет суть «социологического поворота» в литературоведении этой эпохи.

Первый аспект отношения литературы к действительности как предмету изображения далее будем условно именовать онтологическим. Второй аспект, связанный с характеристиками литературы как акта или процесса отражения / преломления, назовем эпистемологическим. 
Обратим внимание, что эта дистинкция не симметрична понятийной паре «содержание» - «форма (стиль)», поскольку содержание может зависеть от социальной оптики, например, жанровой, а форма-соотноситься с характером изображаемого. Так, В. Ф. Переверзев различал стиль помещичьей литературы (включая Гоголя), плавный, последовательный, изобилующий описаниями, исполненный «свежих и сочных красок» (Переверзев, 1982: 216), и «неровный, порывистый» стиль Достоевского - «поэта... городских углов» с его приматом действия над дескрипцией, высокой скоростью повествования, ощущением «странности» происходящего и «фантастическим колоритом» (там же: 205-207). Стиль зависит не только от классового мировоззрения, но и от самих изображаемых «форм жизни» (там же: 190).

Далее я остановлюсь на двух концептуальных метафорах, распространенных в «социологическом» литературоведении 1920-х гг. и характеризующих некоторые любопытные, на мой взгляд, оттенки постулируемых в этих теориях законов социальной эпистемологии литературы.

\section{1. ЗАКОНЫ ОТРАЖЕНИЯ}

«Теория отражения», которую в 1930-40-е гг. выводили прежде всего из статей В. И. Ленина о Л. Н. Толстом (Луначарский, 1934: 84-85), написанных еще в 1908-1911 гг., в сочетании со знаменитыми формулами Ф. Энгельса из письма к М. Гаркнес, опубликованного только в $193^{2}$ году, строилась с акцентом на онтологическую трактовку лежащей в ее основе оптической метафоры. Сама возможность существования такой теории основывалась на том, что в этих публицистических статьях, которые даже не содержали анализа литературных текстов, Ленин говорил об отражении в строго терминологическом смысле, который приписывался этому слову в его философских сочинениях (Мейлах, 1947: 292):

В анализе творчества Толстого Ленин руководствовался сформулированными им в «Материализме и эмпириокритицизме» принципами теории познания. В соответствии с этими принципами Ленин не только вскрыл генетическую связь идей и образов Толстого с исторической действительностью, но и осветил вопрос о правильности отражения Толстым объективных фактов.

Однако именно в этом значении («отражение действительности в литературе») слово «отражение» стало расхожим еще в критике XIX в. Его можно встретить, например, у Н. Г. Чернышевского (Чернышевский, 1949: 617) или П. Н. Ткачева (Ткачев, 1937: 320). В более специфическом марксистском смысле, подразумевающем не просто «правильное» 
миметическое воспроизведение «объективных фактов», но и их идеологическую интерпретацию, это понятие присутствует у Плеханова, раньше Ленина обратившегося к проблеме влияния классовой психологии и идеологии на искусство (Плеханов, 1957: 180).

Но и у самого Ленина семантика «отражения» была не только онтологической, а в онтологическом значении - не такой тривиальной. Уже из его знаменитой статьи «Лев Толстой, как зеркало русской революции» (1908) видно, что Толстой, как «зеркало», отразил вовсе не фактическую действительность революции, а классовое сознание крестьянства как основного, по мнению Ленина, актора первой русской революции.

Как предмет изображения это сознание противоречиво (Ленин, 1925: 117):

Толстой отразил наболевшую ненависть, созревшее стремление к лучшему, желание избавиться от прошлого, - и незрелость мечтательности, политической невоспитанности, революционной мягкотелости.

Но противоречивость изображаемого ленинским Толстым крестьянского сознания оказывается изоморфной самому «отражающему» сознанию. В своем отклике на смерть писателя Ленин пишет (Ленин, 1926: 323$)$ :

Толстой отражает их настроение так верно, что сам в свое учение вносит их наивность, их отчуждение от политики, их мистицизм, желание уйти от мира, «непротивление злу», бессильные проклятья по адресу капитализма и «власти денег». Протест миллионов крестьян и их отчаяние-вот что слилось в учении Толстого.

Противоречия одного порядка отражают противоречия другого порядка, индивидуальное воображаемое писателя отражает коллективное воображаемое целого класса.

Еще один слой противоречий связан с характеристикой природы самого творчества и интеллектуальной биографии Толстого: аристократ становится выразителем идеологии угнетенного класса. Каким образом? Ответ на этот вопрос дает ключ к эпистемологическому измерению закона отражения. Ленин говорит (там же: 322 ):

Острая ломка всех старых устоев деревенской России обострила его внимание, углубила его интерес к происходящему вокруг него, привела к перелому всего его миросозерцания. По рождению и воспитанию Толстой принадлежал к высшей помещичьей знати в России, - он порвал со всеми привычными взглядами этой среды и, в своих последних произведениях, обрушился 
с страстной критикой на все современные государственные, церковные, общественные, экономические порядки, основанные на порабощении масс, на нищете их, на разорении крестьян и мелких хозяев вообе, на насилии и лицемерии, которые сверху донизу пропитывают всю современную жизнь.

Версия Ленина существенно отличается от версии Плеханова и его последователей В. М. Фриче, В. Ф. Переверзева и др. У них (мы к этому еще вернемся) автор всегда остается в горизонте идеологии своего класса. У Ленина гениальный писатель может выйти за ее пределы, реализовав тем самым критический потенциал своего искусства. Но это не является ни его персональной заслугой, ни сознательным решением, коль скоро его выбор непосредственно предопределен «эпохой ломки» - исторической необходимостью. Как показал впоследствии Б. М. Эйхенбаум, изучив идейный контекст ленинской концепции, в решении гениального автора диалектически соединяются «стихийность» и «сознательность», объективность и субъективность (Эйхенбаум, 1969: 68-73). Добавим: в этой перспективе онтологическая и эпистемологическая функции отражения фактически совпадают, поскольку произведения такого гения, воплощающие его социальное воображаемое как выражение идеологии, противостоящей идеологии его собственного класса, репрезентируют не что иное, как классовую борьбу. Здесь-то и возникает возможность прочтения Ленина, согласно которому литература способна объективно отражать социально-историческую действительность как таковую, а не одну из ее идеологических версий. Сам Ленин такого хода не делает и в этом остается последовательным сторонником эпистемологической заданности литературной оптики: ведь даже гений не способен подняться над этой заданностью, а его тексты приобретают критическую силу только при условии их надлежащей деконструкции (а не просто критического чтения).

До того как советское литературоведение приступило к конструированию официальной «теории отражения», основываясь на «толстовском» цикле Ленина, в «социологической поэтике» преобладало влияние идей Плеханова, которые в общем и целом сводятся к чисто эпистемологической трактовке классовой оптики литературы. Более того, в 1920-е гг. мы нередко видим сопротивление онтологическому (реалистическому) толкованию этой теоретической метафоры. Концепции отражения не принимали, например, критики Лефа. С их точки зрения, идеология не только проникает в произведение без ведома автора, но и определяет его именно на уровне оптики, каковой является художественная форма. 
С. М. Третьяков выдвинул лозунг: «Идеология в форме» (Третьяков, 1928: 1). В.В. Тренин писал, что роман

не может фиксировать факты, он не может быть «отображением действительности», потому что сюжетная конструкция нейтрализует реальный материал, лишая его всех специфических качеств (Тренин, 1996: 33).

Пожалуй, наиболее последовательно решающее влияние классовой психологии на литературу отстаивали в своих теориях Фриче и Переверзев. Конкретизируя метафору отражения, в искусстве как форме идеологии, то есть «ложного сознания», они видели преимущественно механизм искажения, по сути исключая возможность «правдивого изображения» действительности.

Со ссылкой на Плеханова, критиковавшего идею художественного изображения как «отражения жизни» (Плеханов, 1922: 126), Фриче, словно оппонируя Ленину, заявляет (Фриче, 1922: 28):

Основное положение марксистской социологии о классовом характере всякого искусства отнюдь не опровергается тем фактом, что иногда писатели или художники фрондируют против своего класса, больше даже, презирают его, отрекаются от него.

Ленин, впрочем, как мы убедились, тоже был далек от того, чтобы предполагать возможность объективного надклассовго или внеклассового «отражения жизни» в литературе. Однако Фриче (как и Плеханов) не допускает даже смены классовой оптики художника (там же):

Так, напр., французские романтики были явно в контрах с французской буржуазией, поглощенной до ушей копеечными интересами и идеалами, и «это пренебрежительное отношение „тонко“ чувствующей élite к „тупым буржуа“ и до сих пор вводит в заблуждение наивных людей, решительно неспособных понять, благодаря ему, архибуржуазный характер романтиков».

Не менее скептически Фриче (вслед за Плехановым) смотрит на концепцию гения, способного - пусть и неосознанно - вскрывать исторические противоречия эпохи и представлять интересы угнетенных в классовой борьбе. Гений может лишь лучше других артикулировать идеологию своего класса, пусть и в формах, кажущихся критическими по отношению к ней (там же).

Классовой психологией и Переверзев, и Фриче объясняют не только содержание, но и формальную структуру произведения. У обоих теоретиков идеологическая субстанция пронизывает все уровни литературыот отдельного текста до творчества писателя как единого целого, от 
отдельного жанра до стиля эпохи. При том что теории Переверзева и Фриче сходятся по многим пунктам поэтики жанра и стиля, они значительно отличаются друг от друга в том, что касается природы идеологического искажения в литературе.

Подход Фриче можно назвать прагматическим, он сосредоточен на субъективных классовых интересах литературного производства. Для него литература не представляет собой пассивное выражение «психоидеологии» того или иного класса, а «служит средством упрочить положение класса» и является его орудием в классовой борьбе (Марксистское искусствознание.., 1930: 25).

Переверзев, напротив, эссенциалист: с его точки зрения, «социальный характер», воплощенный в стиле произведения, не есть индивидуальное или коллективное «я», имеющее какую-то цель или даже сознание, это-часть самого социально-экономического «бытия», и в этом отношении он объективен. Теоретик создает свою версию закона отражения закон «проекции». Проекцией «социального характера», объективированного в произведении, являются не только антропоморфные образы героев, но и «образ» в широком смысле, а также-сам литературный стиль, имеющий не индивидуальный, а классовый характер. И содержание, и форма оказываются подчинены «социальному характеру», который является не только тем, кто отражается в зеркале искусства, но и самим этим зеркалом. Объективность литературы, по Переверзеву, заключается и в том, что она репрезентирует общественное «бытие», и в том, что само это «бытие» высказывается в идеологических формах литературы: социально-экономическая реальность «является в отношении поэтического создания не только изображаемым объектом, но и изображающим субъектом» (Литературоведение, 1928: 14). Эпистемологические характеристики отражения / проекции (классовой оптики) совмещаются с онтологическими (социальным «бытием»), но совсем иначе, чем у Ленина.

Несмотря на то, что Фриче настаивает на субъективно-заинтересованном взгляде художника на изображаемый мир, а Переверзев в центр своей эстетики ставит «социальный характер», оба теоретика отрицают какую-либо роль авторской воли в творческом процессе. Субъективность у Фриче является коллективной и, по существу, безличной, а переверзевский «социальный характер» определяется типовыми «формами жизни», складывающимися в ходе общественного развития и конституируемыми в конечном счете единственным фактором - производственным процессом. 
В разное время теории Фриче и Переверзева в советском литературоведении причислялись к «вульгарному социологизму». Первоначально, на рубеже 1920-30-х гг., после соответствующей «проработки» этого статуса удостоилась только «переверзевщина»; позднее та же участь постигла и школу Фриче (Кожинов, 1962: 1062-1064). Причем свидетельством «вульгарности» была не столько экстерналистская трактовка литературы, сводящая ее форму и содержание к внешним воздействиям, сколько механистичность связи «литературного ряда» с социальными факторами. Однако при желании в механицизме можно обвинить и Ленина, который тоже не объясняет, каким именно образом писатель выбирает идеологическую оптику для изображения сознания революционного класса, какому эпистемологическому закону он следует. На этот счет более продуманными выглядят именно теории «вульгарного социологизма», в которых сегодня, например, обнаруживают вовсе не механицизм, а напротив - принадлежность к традиции «органической поэтики» (Раков, 2002). Вероятно, и в годы становления сталинского литературоведения настоящей проблемой был не механицизм этих подходов, а их теоретический радикализм, не позволявший в «неудобных» классиках снисходительно увидеть соратников и предшественников советской литературы, во многом заблуждавшихся, но все же сумевших «гениально» и «правдиво» отразить «историческую действительность» в духе «критического реализма». В более широкой перспективе, возможно, имеет смысл говорить не о грубо механистическом соединении социальной проблематики и вопросов поэтики, а о слишком высокой степени обобщения, глобальном масштабе всех этих теорий-и «вульгарных», и «подлинно марксистских ${ }^{2}$. Базовые интуиции были впоследствии развиты в западном нео- и постмарксизме, сумевшем значительно детализировать представления о связи литературы и идеологии.

Однако уже в 1920-е гг. возникла теория, которую в координатах тех лет сложно счесть чисто марксистской, но которая во многом восполняет указанные дефициты описанных версий закона отражения.

\section{2. ЗАКОНЫ ПРЕЛОМЛЕНИЯ}

«Социологическая поэтика» П. Н. Медведева, М. М. Бахтина и В. Н. Волошинова, выдвинутая прежде всего в их книгах 1928-1929 гг., будучи одной из попыток синтезировать формализм и «социологический»

${ }^{2} \mathrm{~K}$ последним со временем стали относить даже «переверзевщину», правда, с указанием на ряд «ошибок» (Поляков, 1982: $5^{-} 3^{8}$ ). 
подход (наряду с «социолого-синтетической» моделью П. Н. Сакулина и «формально-социологическим методом» Б. И. Арватова и др.), предложила теоретическую метафору, альтернативную отражению, преломление. Концепция «законов идеологического преломления» была осмыслена в работе Медведева «Формальный метод в литературоведении. Введение в социологическую поэтику», затем представлена в виде аналитического кейса в бахтинской книге «Проблемы творчества Достоевского», а также отчасти в «Марксизме и философии языка» Волошинова. Остановимся на первом из этих трудов.

Медведев рассматривает литературу как одну из областей «идеологического творчества». С одной стороны, литература вполне определяется законами исторического развития общества (автор солидаризуется с основными тезисами классического марксизма о «базисе» и «надстройке», о классовом характере социального знания, о диалектике как главном законе истории и т.д.). С другой стороны, литература наделена рядом специфических черт, которые противопоставляют ее другим формам «идеологического общения».

Исходя из этого, ставятся под вопрос как формалистическая трактовка имманентных законов литературной эволюции, так и различные марксистские виды теории отражения социального в литературе, а также- разного рода попытки примирить идею автономии литературного ряда с учением о социально-экономических закономерностях истории. «Социологическая поэтика» изучает не расхождение и не взаимодействие двух разных законов - она исследует «закон идеологического преломления» на территории самой литературы. Последняя при этом является по сути экстерриториальной по отношению к самой себе как имманентному ряду. Именно подчиняясь внутреннему закону, литература следует закону внешнему.

Оптическая метафора преломления у Медведева обозначает одновременно то, как социально-экономическое бытие репрезентируется в «идеологических значениях», и то, как эти значения воплощаются в художественных формах. Литература отражает не само социальноэкономическое бытие, а то, как оно отражено в первичной «идеологической среде» познания и этоса. Примечательно, что преломление у Медведева выступает то как модификация отражения, то как нечто принципиально иное.

Эти терминологические варианты фиксируют существенно разнящиеся значения. Метафора отражения подразумевает скорее воспроизводство и удвоение социальной действительности в литературе. Этот 
смысл важен для Медведева в том числе как отсылка к классической теории мимесиса, а также в тех случаях, когда он обсуждает возможность проекции судьбы героя на судьбу читателя. Но в целом концепция произведения как системы подобий не соответствует отстаиваемой им идее литературы как активной силы, занятой производством новых форм идеологии. Поэтому метафора преломления, которая предполагает активное воздействие среды на проходящую сквозь нее «идеологическую вещь», по сути, концептуально вытесняет исходную метафору «отражения», более характерную для работ, выполненных в духе «социологического метода» 1920-х гг.

Кроме того, в книге есть еще одна метафора 3 , описывающая взаимодействие социального знания и литературы. Это метафора перевода. Она появляется, когда говорится о роли литературной критики, которая «дает художнику „социальный заказ“ на его собственном языке как поэтический заказ», хотя

при высокой художественной культуре и само общество, сама читательская масса естественно и легко совершает перевод социальных требований и нужд на имманентный язык поэтического мастерства (Медведев, 2018: 79).

Впрочем, этот образ автор не наделяет значимым статусом закона. Итак, в отличие от отражения, семантика преломления с самого начала предполагает смещение акцента с онтологического отношения текста и реальности на эпистемологию-сам механизм претворения социальных значений в произведение.

Почему вообще приходится говорить о преломлении как о законе? Ведь представления Медведева о закономерном значительно отклоняются от преобладающей в теории 1910-20-х гг. тяги к чистой номотетике.

Первый аспект осмысления закона в книге - это свойства элементов, которые подвергаются упорядочиванию с помощью этого закона.

Поскольку науку Медведев рассматривает как одну из форм идеологии, то преобладающий в ней «закон идеологического преломления» противопоставляется тому, который господствует в искусстве. Наука,

3Встречается в работе и слово «проекция», но в значении, противонаправленном переверзевскому: не художественные элементы являются проекциями социальных сил, а, наоборот, «герой и событие сюжета» могут находить себе «наивные непосредственные проекции в жизни» (Медведев, 2018: 58). Так или иначе, анализ таких проекций, по Медведеву, неприемлем для «настоящего социолога», который должен исследовать и форму, и содержание литературного текста «именно как элементы художественной структуры» (там же). 
склонная к «количественному постижению действительности», изучает «абстрактные закономерности», реализующиеся в повторяющихся элементах. Напротив, искусство имеет дело с качественными характеристиками и представляет собой «конкретную ориентацию глаза и всего организма в мире зримых форм» (Медведев, 2018: 95).

Поэтому «социологическая поэтика», изучающая искусство, фактически отрицает важнейшую логическую операцию, обычно применяемую в естествознании и в ориентированных на него социальных науках, а именно - типизацию повторяющихся явлений. В то же время ее подход не является и идеографическим в чистом виде. Она исследует не индивидуальное, а типическое. При этом тип мыслится не как структурный инвариант, реализующийся в серии вариантов, а скорее как единичный предмет, вмещающий в себя «бесконечную смысловую перспективу введенных в него идеологических значений» (там же: 185). Например, жанр как «типическое целое» не является обобщенным посредником между законосообразностью социального и единичностью отдельного произведения или стандартизованной, воспроизводимой моделью текста - скорее это прецедент, исторически конкретный образец, как, например, роман «Дон Кихот», который Медведев, полемизируя со Шкловским, отказывается считать результатом «механистического и случайного» объединения новелл в романное целое.

Однако единичное это не то же самое, что индивидуальное. Законы, интересующие «социологическую поэтику», реализуются только в истории. Типичное и единичное соединены не градуально-иерархическими отношениями абстрактного и конкретного, а «диалектическими» отношениями, разворачивающимися между «большими историческими задачами» «экономического бытия класса» и «краткими явлениями социальной жизни». «Историчность» высказывания у Медведева в одно и то же время означает и его закономерность (то есть типичность и необходимость), и его единичность, специфичность, конкретность. При этом объяснение единичного и конкретного как индивидуального неизменно табуируется. Например, объясняя природу «социальной оценки», Медведев критикует «философию жизни» за сведение оценки к индивидуальному акту.

Оценка социальна, она организует общение. В пределах индивидуального организма и психики она никогда не привела бы к созданию знака, т.е. идеологического тела. Даже внутреннее высказывание (внутренняя речь) социально (там же: 195). 
Исходя из этого, все социальное и все историческое является необходимым и исключает случайное. Случайное относится не к историческому порядку, а скорее к порядку природы или, вернее, к «механическикаузальному» объяснению природы. Например, у формалистов, полагает Медведев, литература превращается в «природную вещь», а «словесные законы оказываются чисто природными физиологическими законами» (Медведев, 2018: 113). Закон «автоматизации-ощутимости» и законы литературной эволюции, на базе которых строится формалистская история литературы, не являются, по Медведеву, ни историческими, ни эволюционными. Во-первых, в них отсутствует диалектическая логика смены историко-литературных эпох: когда «диалектическое отрицание рождается и зреет в лоне самого отрицаемого», как «социализм зреет в лоне капитализма» (там же: 243). Во-вторых, закон «канонизации младшей ветви» не может объяснить возникновение нового в искусстве, ибо описывает литературное развитие как бесконечную рекомбинацию одних и тех же форм. Кроме того, сама смена этих форм носит случайный характер. В противоположность этому, в истории «если бы державинская традиция предопределяла пушкинскую, то она не могла бы явиться снова после пушкинской, и обратно» (там же: 241). Поэтому литературная эволюция формалистов совершается не в истории, а в «какой-то вечной современности».

Показательно, что физиологически-натуралистическое объяснение у Медведева постоянно уравнивается с индивидуально-психологическим. Так, более всего его возмущает, что развитие литературы у формалистов происходит как бы с точки зрения некоего индивида, который наблюдает его и решает, какая форма перестала быть ощутимой и чем ее нужно заменить.

Вся эта схема предполагает существование одного индивида, для которого державинская традиция и сменяется пушкинской. Если он умрет, то может опять повториться пушкинская, - сыну его все равно. Конечно, этот предполагаемый индивид может существовать в бесконечном количестве экземпляров; современников... может существовать очень много. Но современники не составляют исторического человечества (там же: 240).

Это, конечно, reductio ad absurdum, но здесь сходятся все упомянутые характеристики, которые, по Медведеву, не применимы к социальноисторическим законам, в том числе к «закону идеологического преломления». Этот закон не основан на количественных подсчетах тех 
или иных элементов или их итераций, не является результатом абстрагирования, исключает индивидуальное и случайное. Поэтому под подозрение попадают и объективистские объяснения, приравниваемые к «натуралистическому обессмысливанию», и стратегии понимания, которые ассоциируются с психологизмом, субъективизмом и идеализмом. Впрочем, в книге Волошинова «Марксизм и философия языка» парадигма Дильтея в целом признается, однако за вычетом именно этих трех компонентов.

Вторая линия концептуализации закона в книге касается не самих элементов закономерности, а того, как именно закон на эти элементы воздействует.

Первый вопрос: является ли закон трансцендентным или имманентным по отношению к регламентируемой им реальности?

Медведев отвечает на него в характерном парадоксалистском духе: литературное произведение, с одной стороны, является замкнутым на себя целым, а с другой, оно насквозь социологично, то есть детерминировано извне. Настоящая имманентность всегда трансцендентна. Интересно, что подлинно имманентного объяснения литературы как таковой, по Медведеву, до сих пор не существует. Попытка формалистов не удалась именно потому, что их теория не была по-настоящему имманентной, так как стремилась объяснить не развитие самой литературы как «социального общения», а изменения психофизиологической моторики ее восприятия, а это - внешний фактор.

Ответ подсказывает сама логика имманентности. Социальное имманентно литературе, так как она не есть сторонний наблюдатель или объективная оптическая машина, улавливающая и фиксирующая социальные закономерности. Она, как и другие идеологические силы в обществе, сама вовлечена в игру. И хотя произведения, жанры и воплощенные в их «идеологическом теле» социальные оценки представляют собой «поэтические объективации», Медведев подчеркивает, что сама «идеологическая среда», частью которой является литература, находится в постоянном становлении, ее объективировать нельзя. Более того, та законосообразная действительность, которая в ней преломляется, есть не само социальное бытие, а знание о нем, то есть социальное бытие, уже прошедшее идеологическое преломление в повседневной жизни - в этике, познании, политике, религии и т. д. Поэтому слово как «идеологическая вещь» материально и объективно, но не так, как 
материальны и объективны физическое тело, природный объект, орудия производства и продукты потребления. По сути, оно объективно в современном конструктивистском смысле.

Например, то, как Медведев рассуждает о характере изображения реальности в реалистическом романе, сильно напоминает / предвосхищает логику структуралистского анализа, который подразумевает, что текст изображает не саму действительность, а культурные представления о ней, участвующие в ее конструировании. Более того, Медведев замечает, что та или иная «этико-философская идеологема», которая попадает в литературу, оказывается «вовлечена в поток становящейся идеологии» (Медведев, 2018: 53). Поэтому, например, Базаров, как этико-философская и политическая идеологема, становится всего лишь частью художественной идеологемы романа. Но и в этом виде он является «таким же социальным выступлением, как и этико-философское, политическое и всякое иное идеологическое выступление» (там же: 6о), то есть продолжает участвовать в «социальном общении» и идеологическом становлении.

Галин Тиханов считает, что теорию жанра Медведева и раннего Бахтина отличает две важнейших позиции. Первое: то, «что понятие жанра... включает в себя эпистемологическую установку в отношении действительности», то есть жанр не просто фиксирует какой-то социальный опыт, но и содержит исторические представления о закономерностях этого опыта. Второй момент: по Тиханову,

позиция Бахтина / Медведева предполагает за жанром весьма высокую активность. Попытка сломать преграды классической марксистской теории искусства, приписывающей литературе и литературным жанрам лишь пассивную роль некоей сверхструктуры, подразумевает функцию контроля жанров над определенными аспектами реальности. Жанры больше не отражают мир: скорее, они моделируют его (Тиханов, 1996: 125).

Будучи одной из идеологических форм, литература в то же время является рефлексивной надстройкой над другими идеологиями. Жанр как эпистемологическая оптика не только воспроизводит существующие социальные представления, но и оценивает и понимает их. При этом литература наравне с рефлексируемыми ею идеологиями участвует в общественной дискуссии, то есть она политична в широком смысле слова. Идеология - это не только социальное знание о мире, которое служит ориентации в нем (вопрос о его ложности или истинности здесь выносится за скобки). В пределе это также и инструмент изменения общества. 
Отсюда, кстати, двухуровневая модель преломления у Медведева и Бахтина: произведение, с одной стороны, воспроизводит существующие социально-эпистемологические установки («первичное идеологическое преломление»), с другой стороны, активно оценивает, то есть пересобирает и переозначивает их («вторичное идеологическое преломление»).

Конечно, понимание идеологии, характерное для «бахтинского круга», резко контрастирует со стереотипным марксистским представлением о ней как о неосознанном, безлично-принудительном социальном знании. Однако такая трактовка, полагаю, могла бы дать более убедительное объяснение тому, как возможно критическое искусство в условиях тотальной идеологичности, чем это получилось у Ленина, так как, преломляя существующие идеологии, искусство их не только пассивно воспроизводит, но и делает ощутимой саму искажающую идеологическую оптику. В порядке фантазии можно назвать это своего рода идеологическим остранением, в чем-то аналогичным формалистскому, но захватывающим несвойственную формалистам тему содержания искусства и содержательности художественных форм. Если это верно, то можно утверждать, что в концепции преломления онтологическая проблематика «отображения жизни» оказывается как бы поглощена проблематикой эпистемологической. Интересно, что у Медведева эта возможность активного действия в идеологической среде не противоречит представлениям об историческом детерминизме и облигаторности общественных законов. Поскольку «закон идеологического преломления» представляет собой имманентное трансцендентное, то он не обладает императивной силой внешнего принуждения, как закон отражения у других «социологов». Скорее он реализуется через саму «художественную волю» писателя, подразумевает его преобразующую творческую активность.

Характерно также, что теоретическая программа «бахтинского круга» в определенном смысле развивает и формалистский проект. Так, в «Проблемах творчества Достоевского» Бахтин показывает, что участие в идеологическом становлении писатель и текст принимают только в свое время, в актуальном контексте. Для потомков «имманентная социологичность» произведения отходит на второй план, а художественная форма, отделяясь от идеологии автора, которая «уже ушла», включается в имманентный литературный ряд (Бахтин, 200о: 42). Историк может вернуться к общественной ситуации и реконструировать идеологическую среду, в которой сформировалось социальное воображаемое 
писателя, рассматривая порожденную этой средой поэтическую конструкцию как «социологический документ». Сам Бахтин слагает с себя обязанности такой исторической реконструкции, ограничиваясь только описанием жанровой инновации Достоевского, однако попутно намечает также и ключевые направления «имманентно-социологического» анализа в контексте эпохи ${ }^{4}$ Х Художественная форма, словно искусственный кристалл, хранит память не только о тех силах, которые отшлифовали его грани, но даже о «лучах социальной оценки», некогда преломлявшихся в нем (Бахтин, 200о: 7).

\section{ЛИТЕРАТУРА}

Бахтин М. М. Собрание сочинений. В 7 т. Т. 2 / под ред. С. Г. Бочарова, Л. С. Мелиховой. - М. : Русские словари, 2000.

Зенкин C. Н. Работы о теории. - М. : Новое литературное обозрение, 2012.

Кожинов В. В. Вульгарный социологизм // Краткая литературная энциклопедия. В 9 т. Т. 1 / под ред. А. А. Суркова. - М. : Советская энциклопедия, 1962. - С. $1062-1064$.

Корчинский A. B. Политика полифонии : Опасная современность и структура романа у Достоевского и Бахтина // Новое литературное обозрение. 2019. - № 155. - С. $27-41$.

Литературоведение / под ред. В. Ф. Переверзева. - М. : Изд-во ГАХН, 1928.

Луначарский A. В. Ленин и литературоведение. - М. : Советская литература, 1934 .

Марксистское искусствознание и В.М. Фриче / под ред. и. и. я. Секции литературы. - Загорск : Изд-во Комакадемии, 1930.

Материалы диспута «Марксизм и формальный метод: 6 марта 1927 г.»// Новое литературное обозрение / под ред. Д. Устинова. - 2001. - № 50. - С. $247^{-278}$.

Мейлах Б. С. Ленин и проблемы русской литературы конца ХІХ-начала ХХ вв. Исследования и очерки. - М. : ОГИЗ, 1947.

Плеханов Г. В. Избранные философские произведения. В 5 т. Т. 3 / под ред. М. Т. Иовчука, А. Н. Маслина, П. Н. Федосеева. - М. : Госполитиздат, 1957. Поляков М. Я. В.Ф. Переверзев и проблемы поэтики // Гоголь. Достоевский. Исследования / В. Ф. Переверзев. - М. : Советский писатель, 1982. - С. $5^{-} 3^{8}$. Раков В. П. Новая «органическая» поэтика (Литературные теории В.Ф. Переверзева, В. М. Фриче и П. Н. Сакулина). - Иваново : Ивановский государственный университет, 2002.

Сухих С.И. Социологическая поэтика в русском литературоведении І-й половины хх века. - Иваново : Ивановский государственный университет, 2006.

4Подробнее об этом см. мою статью Корчинский, 2019. 
Тиханов Г. Бахтин, Лукач и немецкий романтизм // Диалог. Карнавал. Хронотоп. - 1996. - № 3. - С. 117-142.

Ткачев П. Н. Избранные сочинения на социально-психологические темы. В 6 т. Т. 6 / под ред. Б. П. Козьмина. - М. : Издательство Общества политкаторжан и ссыльнопоселенцев, 1937 .

Тренин В. Тревожный сигнал друзьям // Новый ЛЕФ. - 1996. - № 8. - С. 30-36.

Третьяков С. С новым годом, с новым Лефом // Новый ЛЕФ. - 1928 . № 1. - C. $1-3$.

Фриче В. М. Г. В. Плеханов и «научная эстетика» // Искусство : Сборник статей / Г. В. Плеханов. - М. : Новая Москва, 1922. - С. 21-36.

Эйхенбаум Б. М. О прозе. - Л. : Художественная литература, 1969.

Медведев П. Н. Т. 2 / под ред. Ю. П. Медведева, Д. А. Медведевой. - 2018.

Чернышевский Н. Г. Т. 2 / под ред. Н. М. Чернышевской. - 1949.

Aucouturier $M$. Le «Léninisme» dans la critique littéraire soviétique // Cahiers du Monde russe et soviétique. - 1976. - T. 17, n 4. - P. 411-426.

Ermolaev H. Soviet Literary Theories, 1917-1934 : The Genesis of Socialist Realism. Berkeley : University of California Press, 1977.

Rubin B. Plekhanov and Soviet Literary Criticism // The American Slavic and East European Review. - 1956. - Vol. 15, no. 4. - P. 527-542.

Korchinskiy, A. V. 2021. "Opticheskiye zakony literatury [Optical Laws of Literature]: tekst i deystvitel'nost' v sovet-skoy 'sotsiologicheskoy poetike' 1920-kh gg. [Text and Reality in Soviet 'Sociological Poetics' of the 1920s]' [in Russian]. Filosofiya. Zhurnal Vysshey shkoly ekonomiki [Philosophy. Journal of the Higher School of Economics] 5 (2), 123-142.

ANATOLIY KORCHINSKIY

PhD in Philology; Associate Professor

Historical-Philologycal Faculty, Institute of History and Philology, Russian State UNIVERSITY FOR THE HUMANITIES (MOSCOW, RUSSIA); ORCID: 0000-0002-5087-2531

\section{OPTICAL LAWS OF LITERATURE}

\section{Text and Reality in Soviet "Sociological Poetics" of the 1920 S}

Submitted: Nov. 15, 2020. Reviewed: Feb. 25, 2021. Accepted: Mar. 03, 2021.

Abstract: The article considers several scientific metaphors describing the regularities of relations between literature and reality in the Soviet "sociological" literary theory of the 1920s. The most productive of these conceptual metaphors - reflection and refraction - reveal the features of key Marxist theories - Plekhanov, Lenin, Friche, Pereverzev, Medvedev, Bakhtin, Voloshinov, etc. The tendency towards the development of universal scientific laws as applied to cultural phenomena, which is characteristic of the epoch, is noted, in particular, the leveling of the author's role in the historical and literary process and the critical potential of art associated with it. There are analyzed the different strategies of interpretation of basic 
theoretical metaphors interpreted, first of all, as reflection/ refraction of social reality in literature. Two aspects of the problem of reflection/refraction are discussed-ontological, implying a "true image" of reality, and epistemological, which assumes that literature reproduces not the reality itself, but the social optics of its understanding. The author of the article shows that optical metaphors make it possible to understand which theories imply greater dependence of the literature on prevailing social notions, and which ones - greater independence, flexibility and variability of the law of reflection/refraction. In this light, the poles of "sociological poetics" - the theory of Friche and Pereverzev - are considered as sequential versions of ideological determinism, Lenin's approach as a kind of deconstruction of literary ideology, and the method of "Bakhtin's circle" as the most soft version of "sociologism", which combines it with some provisions of the formal school.

Keywords: "Sociological Poetics", "Sociological Method", "Reflection Theory", "Ideological Refraction Law", Class Psychology, Ideology, Marxism, Formalism.

DOI: $10.17323 / 2587-8719-2021-2-123-14^{2}$.

\section{REFERENCES}

Aucouturier, M. 1976. "Le 'Léninisme' dans la critique littéraire soviétique" [in French]. Cahiers du Monde russe et soviétique 17 (4): 411-426.

Bakhtin, M. M. 200o. [in Russian]. Vol. 2 of Sobraniye sochineniy [Collected Works], ed. by S. G. Bocharov and L. S. Melikhova. 7 vols. Moskva [Moscow]: Russkiye slovari.

Chernyshevskiy, N. G. 1949. . Ed. by N. M. Chernyshevskaya. Vol. 2.

Eykhenbaum, B. M. 1969. O proze [About the Prose] [in Russian]. Leningrad: Khudozhestvennaya literatura.

Ermolaev, H. 1977. Soviet Literary Theories, 1917-1934: The Genesis of Socialist Realism. Berkeley: University of California Press.

Friche, V. M. 1922. "G. V. Plekhanov i 'nauchnaya estetika' [G. V. Plekhanov and 'Scientific Aesthetics']" [in Russian]. In Iskusstvo [Art] : Sbornik statey [Collection of Articles], by G. V. Plekhanov, 21-36. Moskva [Moscow]: Novaya Moskva.

Korchinskiy, A. V. 2019. "Politika polifonii [The Politics of Polyphony]: Opasnaya sovremennost' i struktura romana u Dostoyevskogo i Bakhtina [Dangerous Modernity and the Structure of the Novel in Dostoevsky and Bakhtin]" [in Russian]. Novoye literaturnoye obozreniye [New Literary Observer], no. 155: 27-41.

Kozhinov, V. V. 1962. "Vul'garnyy sotsiologizm [Vulgar Sociologism]" [in Russian]. In vol. 1 of Kratkaya literaturnaya entsiklopediya [Short Literary Encyclopedia], ed. by A.A. Surkov, 1062-1064. 9 vols. Moskva [Moscow]: Sovet.skaya entsiklopediya.

Lunacharskiy, A. V. 1934. Lenin i literaturovedeniye [Lenin and Literary Criticism] [in Russian]. Moskva [Moscow]: Sovet-skaya literatura.

Medvedev, P. N. 2018. . Ed. by Yu. P. Medvedev and D. A. Medvedeva. Vol. 2.

Meylakh, B. S. 1947. Lenin i problemy russkoy literatury kontsa XIX-nachala XX vv. Issledovaniya $i$ ocherki [Lenin and the Problems of Russian Literature of the late XIX-early $\mathrm{xx}$ Centuries. Research and Essays] [in Russian]. Moskva [Moscow]: OGIZ.

Pereverzev, V. F., ed. 1928. Literaturovedeniye [Literary Studies] [in Russian]. Moskva [Moscow]: Izd-vo GAKhN.

Plekhanov, G.V. 1957. [in Russian]. Vol. 3 of Izbrannyye filosofskiye proizvedeniya [Selected Philosophical Works], ed. by M. T. Iovchuk, L. N. Maslin, and P. N. Fedoseyev. 5 vols. Moskva [Moscow]: Gospolitizdat. 
Polyakov, M. Ya. 1982. "V. F. Pereverzev i problemy poetiki [V. F. Pereverzev and Problems of Poetics]" [in Russian]. In Gogol'. Dostoyevskiy. Issledovaniya [Gogol. Dostoevsky. Researches], by V.F. Pereverzev, 5-38. Moskva [Moscow]: Sovet-skiy pisatel'.

Rakov, V.P. 2002. Novaya "organicheskaya" poetika (Literaturnyye teorii V. F. Pereverzeva, V. M. Friche i P. N. Sakulina) [New "Organic" Poetics (Literary Theories of V.F. Pereverzev, V. M. Fritsche and P. N. Sakulin)] [in Russian]. Ivanovo: Ivanovskiy gosudarstvennyy universitet.

Rubin, B. 1956. "Plekhanov and Soviet Literary Criticism." The American Slavic and East European Review 15 (4): 527-542.

Sektsiya literatury, iskusstva i yazyka, ed. 1930. Marksist.skoye iskusstvoznaniye i V.M. Friche [Marxist Art Studies and V. M. Fritsche] [in Russian]. Zagorsk: Izd-vo Komakademii.

Sukhikh, S. I. 2006. Sotsiologicheskaya poetika v russkom literaturovedenii I-y poloviny Xx veka [Sociological Poetics in Russian Literary Studies of the First Half of the XX Century] [in Russian]. Ivanovo: Ivanovskiy gosudarstvennyy universitet.

Tikhanov, G. 1996. "Bakhtin, Lukach i nemetskiy romantizm [Bakhtin, Lukacs and German Romanticism]" [in Russian]. Dialog. Karnaval. Khronotop [Dialogue. Carnival. Chronotope], no. 3: 117-142.

Tkachev, P. N. 1937. [in Russian]. Vol. 6 of Izbrannyye sochineniya na sotsial'no-psikhologicheskiye temy [Selected Essays on Socio-Psychological Topics], ed. by B. P. Koz'min. 6 vols. Moskva [Moscow]: Izdatel'stvo Obshchestva politkatorzhan i ssyl'noposelentsev.

Trenin, V. 1996. "Trevozhnyy signal druz'yam [Alarm Signal to Friends]" [in Russian]. Novyy LEF [The New Left Front of the Arts], no. 8: 30-36.

Tret'yakov, S. 1928. "S novym godom, s novym Lefom [Happy New Year, Happy New LEF]" [in Russian]. Novyy LEF [The New Left Front of the Arts], no. 1: 1-3.

Ustinov, D., ed. 2001. "Materialy disputa 'Marksizm i formal'nyy metod: 6 marta 1927 g.' [Materials of the Debate 'Marxism and the Formal Method: March 6, 1927']" [in Russian]. Novoye literaturnoye obozreniye [New Literary Observer], no. 50: 247-278.

Zenkin, S. N. 2012. Raboty o teorii [Works on Theory] [in Russian]. Moskva [Moscow]: Novoye literaturnoye obozreniye. 